\title{
Religious Conversion of the Ethnic Minorities in the South of Vietnam
}

\author{
Truong Phan Chau Tam*
}

\begin{abstract}
Religious conversion is a phenomenon that has frequently occurred in human history. As part of religious life, religious conversion reflects fluctuations and changes in social existence, especially changes in the economic, cultural, social, religious factors and one's own subjective religious convictions. Religious conversions are taking place in the ethnic communities in Southern Vietnam, but in a context that is space and time specific. So the process of evolution, the nature, dynamics and characteristics of the case of religious conversion here is different and unique. Currently, the study of religious conversion in Vietnam in general and the South in particular, is modest. There have not been many studies regarding case specific religious conversion of people and no studies have done a full assessment of the nature and characteristics of religious conversion on social life in Southern Vietnam as well as forecasted the evolution and impact of the same. This article is intended to present and describe three cases of religious conversion in the south of Vietnam. These are the conversion to Protestantism of ethnic communities Khmer (originating from Cambodia)
\end{abstract}

* PhD Student, Center for Religion Studies, The University of Social Sciences and Humanities, Vietnam National University, Ho Chi Minh City, Vietnam; crshcm@hcmussh.edu.vn 
and Stieng, and the case of conversion to Yiguandao of the Chinese community (derived from Chinese). This article tries to select principles and theoretical approaches of Western scholars in the study of the religious conversion of three ethnic groups in the hope of understanding the process of conversion that offers a distinct perspective.

Keywords: Religious conversion; Conversion to Protestantism; Conversion to Yiguandao; Khmer communities; Ethnic communities; Stieng; Chinese community

Religious conversion is a phenomenon that has become a major problem for the minority communities in the south of Vietnam today. The following is a summary and evaluation of research on religious conversion in southern Vietnam. We found that religious conversion not only causes religious life to become more complex and multidimensional but can also be a challenge to the stability and sustainable development of the community of ethnic groups in southern Vietnam ${ }^{1}$. The phenomenon of religious conversion in the southern region has attracted the attention and interest of many researchers in the field of social sciences and humanities.The most recent scientific conference regarding this issue was held in Ho Chi Minh City (HCMC) in 2013, which discussed "Some theoretical and practical issues of religious conversion of the minor communities in the southern region"2. It included many papers on the religious conversion of ethnic communities such as "The movement of religious conversion of the minorities in the South of Vietnam and questions for researching" (Hop, 2013); "The religious conversion of the Khmer in Tra Vinh Province" (Lien, 2013); "The reality of religious conversion of the Khmer in the South of Vietnam" (Quynh and Lam, 2013) and "Religious conversion of the Chinese

1 South, Vietnam includes: Ho Chi Minh City, Binh Phuoc Province, Tay Ninh Province, Binh Duong Province, Dong Nai Province, Ba Ria Vung Tau Province, Long An Province, Tien Giang Province, Cantho Province; Angiang Province; Soctrang Province; Dongthap Province; Camau Province; Haugiang Province; Kiengiang Province; Baclieu Province; Rachgia. Province; Vinhlong Province

2 Southern Social Science Institute 2013 workshop, "Some theoretical and practical issues of religious conversion of ethnic minorities in the Southern region", HCMC. 
community in Ho Chi Minh City - The study case of Yiguandao" (Ngoc, 2013).

The observations in this paper emerge from the work undertaken by the project on religious conversion in the southern Vietnam, by Dr. Truong Van Chung with the support of VNU - HCM and organizations such as Missiso Aachen, Federal Republic of Germany. The project team and the researcher have conducted fieldwork in the provinces and cities in Southern Vietnam. We have performed sociological investigation and in depth interviews with people who have undergone religious conversion. Our research describes this process as follows:

Religious conversion is not a new phenomenon. The history of religion has witnessed the shift from polytheism to Christianity in ancient Rome ${ }^{3}$ (Nock, 1933), from Christianity and Buddhism to Protestantism in some countries in Asia and Europe and Asia in the Mid-Modern period ${ }^{4}$ (Motta, 2009). The most recent are the conversion from traditional religions into new religions in many countries around the world 5 (Chesnut, 2007). The phenomenon of religious conversion has been of interest to Western scholars when researching the history of Christianity, Islam, and Buddhism (Barro, Hwang \& McCleary, 2001).

For understanding the variations of religious conversions, several scholars from the Western world have provided insightful theoretical frameworks. Lewis R. Rambo has remarked that "the theory of conversion is the ground to build the researching goals and methodology, to enable exploration, understanding, and explanation about particular cases of religious conversion."

3 See: "Conversion. The Old and the New in Religion from Alexander the Great to Augustine of Hippo. By A.D Nock. Oxford University Press 1933 (chapter XII: The Spread of Christianity as a social phenomenon. p.187 - 211)

4 See: "Conversion in the Age of Pluralism" General Editor William H. Swatos, Jr. Printed in the Netherlands. 2009. p. 163 - 186

5 See: "Conversion of a Continent - Contemporary religious change in Latin America". Edited by Timothy J. Steigenga and Edward L. Cleary. Rutgers University Press. 2007. p.72 - 93 
(Rambo, 1993). Regarding typology, Lewis R. Rambo and Charles E. Farhadian have remarked that the phenomenon of religious conversion in history is very diverse, with many forms. However, we can tentatively divide these into three basic types of conversion. (Rambo, 1987). One of them is the transformation leading to religious variations, which is the expansion or narrowing of the subject of religious faith, leading to the partial change of religious teachings and religious community activities. (Lofland, John \& Skonov, 1981). The second type is the conversion of polytheism to monotheistic, non-monotheistic or new religions. This is a very diverse and complex type, including not only the conversion from polytheism to monotheistic religion (such as the case of conversion from polytheism to Christianity, Islam, and Judaism) but also the conversion to non-monotheistic religions such as to Hinduism, Buddhism and new religions. ${ }^{6}$

The third form is "proselyte", which is the conversion of religious faith from one religion to another religion such as the conversion from Hinduism to Islam, from Buddhism and Islam to Christianity and Protestantism in Southeast Asian countries in the Mid Modern and Contemporary periods (Lofland, John \& Rodney Stark. 1965, P.37). These scholars also emphasized that these forms of religious conversion were extremely complex and diverse, so their classification only had relative meanings and was appropriated for each religion in specific historical circumstances. Therefore, the theory of conversion could not be generic and cover all forms of conversion. There is no single theory suitable for application to all cases.

Among the types of religious conversions, the study of religion in the West has identified social causes of conversion, which include economic and political changes or cultural rifts. However, they pay special attention to the direct causes leading to the transformation of religion from within as well. In other words, they trace the motivations and processes of conversions through the changes in an individual's belief and religious faith. Changes in one belief

6 See: "The Anthropology of Religious Conversion" Edited by Andrew Buckser and Stephen D. Glazier. Rowman and Littlefield Publishers, INC.2003. P.211 - 223. 
lead to changes in thoughts, behaviors, and rituals. These changes are not specific to individuals but can be extended to understand church organizations and structure of religious communities as well. Western religious studies traditionally emphasized the change from within and usually focused more on the transformation of the religious life of individual believers. This includes a well-known work by Lewis Rambo, which describes the phases of religious conversion in the personal life of an individual, including the background, crisis of belief, spirituality, doubt, searching, meeting and communicating, interacting, commitment and the results of conversion. Regarding this research, Rambo has stated that "I am not saying that my theory of multiple stages is universally applicable, but it is a model that helps us in selecting research options for conversion" (Rambo,1993).

Western scholars in religion studies have successfully applied these theories of religion in the study of conversion from polytheism to Christianity in ancient Rome, (Hefner,1993) from Hinduism to Islam in India (Mujahid,1989) and from traditional religions to new religions (Machalek \& Snow,1993), which has led to significant theoretical and practical outcomes including:

1. Use of theoretical frameworks to clarify and explain specific cases of religious conversion such as the theory of Religious Secularization, the theory of Religious Pluralism, the theory of Rational Choice, and the theory of Social Structure.

2. Focus and emphasis on the inner transformation of religious conviction as a change of religious beliefs, especially the transition of spiritual life itself of individual believers.

3. Attention to phases of transition of individual religious beliefs and distinguishing between self-conversion and religious conversion by external pressures (violence, coercion, brainwashing, specific drugs leading to hallucination, to name a few).

4. Personal and social consequences of religious conversion in one's social life, the challenges to the sustainability of families and society, the conflicts in religious communities 
and individual mental illnesses. (Ullman, 1989) particularly in Europe. ${ }^{7}$

We believe that it is necessary and useful to apply the theories of religious conversion by western scholars. However, we also acknowledge that the culture and religious traditions of Vietnam be taken into serious consideration when studying and researching the phenomenon of religious conversion in the southern region of Vietnam. We therefore propose two basic theoretical frameworks:

1. There is no unique or universal theoretical framework to study all the phenomena of religious conversion in Southern Vietnam. We advocate a multi-theory approach to be able to study each specific case of religious conversion in the context of a multi-ethnic environment, multiculturalism and the characteristics of the southern religions.

2. Research must focus on the cultural, religious, and ethnic characteristics of the southern region to determine the theoretical framework when studying specific conversion phenomena.

Southern Vietnam is a land of diverse ethnicities and different religious beliefs. The history of co-inhabitance of different ethnic communities and acculturation has created unique cultural and religious identities among these communities. Currently, in the context of reformation and international integration process, religious life also has witnessed significant changes. This phenomenon has posed a few urgent questions concerning religious conversion within communities and their social impact. This has now forced researchers and policy makers to pay attention and study these matters in a more systematic manner. One of these is the phenomenon of religious conversion within ethnic communities. This is the case of "conversion" of the Khmer in the

${ }^{7}$ E.G.: Barker, Eileen, The Making of Moonie: Choice or Brainwashing?, Hampshire: Gregg Revivals, 1984. Beckford, James, 'Accounting for Conversion', British Journal of Sociology, 29(2), 249-262. 1978. Clarke, Peter B. (ed.), The New Evangelists: Recruitment Methods \& Aims of New Religious Movements, London: Ethnographica, 1987. 
south western region, the conversion of Stieng and Choro communities in the south eastern to Protestantism and the conversion of the Chinese-Vietnamese to Yiguandao (or I Kuan Tao).

The purpose of this paper is to clarify the impact of religious conversion on the ethnic minorities in the South region. We are aware that there are several other aspects of religious conversion such as the motivations, backdrop, objective and subjective factors, processes, and phases of conversion and acknowledge that these factors are important and need specific attention. However, conforming to the purpose of this specific paper, the observations and analyses in this paper will exclusively focus on the relationship between religious conversion and the life of ethnic communities, in particular, the cases of the Khmer, Chinese Vietnamese, and Stieng people in the southern Vietnam.

We will first discuss religious conversion within the Khmer commune in the Southwestern region. According to statistics, there are currently 2,713 Protestants among ethnic minorities in the Southwest, which is $3.69 \%$ of total 73,493 Protestants within the region. Most of the ethnic Protestants are Khmer people ${ }^{8}$. The majority of Khmer Protestants live in districts of the Tra Vinh Province, such as Tra $\mathrm{Cu}$, Duyen Hai, Tieu Can, Chau Thanh, and Cang Long and belong to the Protestant denominations such as Evangelical Church of Vietnam (297 Khmer followers), The Church of Christ (75 Khmer follower), Vietnam Full Gospel Church (08 Khmer followers), and Vietnam Agape Baptist Church (4 Khmer followers) (Hop, 2013). During fieldwork and interviews, we found that the majority of Khmer followers in the southwest were originally Theravada Buddhists. Therefore, we can understand that this is a case of religious conversion. Though the percentage of Khmer Protestants is not high in the Khmer community in the south, their presence raises a number or family and social issues

8 Government Religion Board, "Conclusion of five years implementing the Instruction \# 01/2005/CT - TTg by the President dated 04/02/2005 on some policies regarding Protestantism", Report ref \# 18/BC - TGCP dated 16/03/2012. 
within the community. Some highlights of the religious conversion of Khmer people in the south of Vietnam include:

1. The center of religious conversion of Khmer people in the south is mainly in Tra Vinh Province and Soc Trang Province which involves two Protestant denominations, Evangelical Church of Vietnam and Protestant Church. According to the Ethnic - Religion Board of Soc Trang Province, Evangelical Church of Vietnam has become a major religious center of the Khmer people in the south with seven worshipping facilities, seven pastors, four missionaries, 73 association members and a total of 3695 followers of which 650 are Khmer people. (Lien, 2013). There are currently 13 Protestant denominations active in Tra Vinh Province and this province has become one of the main centers of religious conversion. The statistics provided by the Ethnic - Religion Board of Tra Vinh province shows that the conversion of Khmer Buddhists to the Protestant denominations is spreading and expanding in the region. In 2012, the number of Khmer people who had converted to the Protestant denomination were over 993 people from over 63 South Khmer households (Quynh \& Lam, 2013).

2. The conversion of minority communities in general and the Khmer community, in particular, is not a spontaneous movement but a conscious, organized and professional activity, as evidenced by the expansion and modernization of facilities and churches, which assist in missionary and conversion activities. The Protestant denominations have founded committees dedicated to missionary work and conversion of the Khmer people and appointed Khmer people to boards in charge of charity, missionary work, and conversion. The use of Khmer people for missionary work and conversion in the South Khmer community has brought positive effects and results.

3. Protestant denominations also regularly organize charity activities, humanitarian aid or direct support that involves providing financial or livelihood support. They help people by providing them monetary support, basic necessities such as food and medicines, bicycles, seeds, helping them create 
lavatories. This aids in their strategies to influence the community and build community networks. These social activities have met the direct and immediate needs in the daily life of the Khmer people, who continue to have a lot of financial difficulties and insufficiencies. In this context, extending the financial and livelihood support becomes a significant factor that affects the conversion of the Khmer people in the south.

4. The conversion of the Khmer community mainly occurs among young people and families of young newly married couples. According to statistics, over $73 \%$ of the Khmer converts are young people (ages 18-30). This phenomenon has many objective and subjective causes and we need more research to understand this comprehensively. However, it has been found and predicted that the phenomenon of conversion has been and will continue to significantly affect the lives of the South Khmer communities.

In general, religious conversion in the southern Khmer community is a new phenomenon generating both positive and negative impacts on the community. We believe that there should be more time specific research projects on this issue to assess further the consequences of this conversion. We should avoid making judgments and drawing hasty conclusions without taking sufficient time to study the phenomenon in increasing detail. Scholars observe that the conversion process of Khmer communities have specific features. They are conducted "publicly and peacefully and comply with the instructions of the Party and the State. There is no conflict or dispute among the denominations" (Quynh \& Lam, 2013). On the other hand, other scholars opine that this phenomenon "is very concerning and serious to Buddhism..." (Than, n.d.). Without choosing one side or the other, we would like to share the statement of Lewis Rambo who states that "Religious conversion is a complex process, with many progressive stages and 
factors interacting with each other in a long time 9 , Therefore, evaluating the impacts of religious conversion to cultural, social and spiritual life should require sufficient time and many comprehensive and multi-dimensional scientific research projects" (Rambo, 1993).

The phenomenon of religious conversion of Chinese Vietnamese in the south has taken place mainly in the south-eastern provinces and cities such as Ho Chi Minh City, Binh Duong Province, Dong Nai Province, and Bien Hoa City. The most noticeable is the religious conversion from traditional Chinese religions to Yiguandao (or I Kuan Tao) ${ }^{10}$. According to a senior dignitary of Yi guandao $^{11}$ (the highest rank in the Yiguandao organization), the religion has over 5000 followers and over 150 groups in the southeastern cities and provinces. Ho Chi Minh City is the largest center, which has the most efficient missionary activities and the fastest growing number of converts. The conversion phenomenon in the Chinese community maybe considered new, although it has been present for more than 20 years. We have very little material and indepth studies on the subject, however, with preliminary observations, fieldworks and looking at the impact of Yiguandao on the social life of the community, we identify the following highlights:

1. Yiguandao is a new form of religion in Taiwan, China. Its characteristic is the fusion of three traditional Eastern religions Buddhism, Confucianism and Taoism. The presence of Christians and traditional culture in Yiguandao, through group activities and small gatherings they spread the doctrine. However, proselytizing is not done in public. Religious activities in the Vietnam Yiguandao society has not been admitted to have caused much concern, worried or necessitated even a response from the social community.

9 The conversion from polytheism to Christianity in the history of Western religion had significant impacts on many areas of social life. However, it could be judged correctly and objectively only a 100 years later.

10 Yiguandao is a new religion in Taiwan China. Currently, Yiguandao have appeared in more than 50 countries around the world

11 Depth -Interview by Nguyen Chien Truong and Tran Hoang Hao. 24/11/2012. 
2. The missionary and conversion methodology of Yiguandao is suitable for its working-class followers who may not be able to understand abstract philosophies. They follow the traditions but may not comprehend the details. In return, they can participate in other activities. On the other hand, Yi Guan Dao has a clear secular nature, which is the adaptation of the religious organization to the changing conditions of society as well as being active in social life and engaging with the community to solve social problems. This connects with the life of the Chinese community today and meets their spiritual needs (Truong (Ed.), 2014).

3. According to the teachings of Yiguandao, a follower practices this religion by paying attention to his or her body and mind in the spirit of Zen, Yi, Qi, and Zhi12. Practitioners are expected to participate in social charity activities. Vietnamese in general and residents of Ho Chi Minh City in particular also have these interests, which are consistent with the ethics of Yiguandao, creating empathy among communities.

4. Conversion to Yiguandao always takes place in the family and among loved ones and from there spreads to the community. This is an effective method of missionary activity in the conversion of Yiguandao. Therefore, the spread of this religion progresses in a gradual but sustained manner.

5. Conversion to Yiguandao not only takes places in the Chinese community but also in the Vietnamese community, mainly among those who used to work in Taiwan and have now returned to Vietnam (Truong (Ed.), 2014). Although the State and the local authorities have not approved the

12 Zen is meditation (a concept of Buddhist Zen school); Yi: God's justice. This is a supreme principle of heaven and earth; Li: Natural air. This is the unity of yin and yang qi (Negative air and positive air); Zhi: celestial object. This is the origin and model of all things. See: "Understanding Yguandao. By Chen Joseph J.F. Publishers Center church teachings of Yguandao. Taiwan. 2009. 
activities of this religion, its groups and worshipping facilities of religious groups have grown and expanded, especially in the provinces and cities in the South-eastern region. ${ }^{13}$

Yiguandao followers in the South-eastern provinces and cities come from various social groups including small traders, office workers, students, homemakers etc. with low incomes and a hard life. They have to work every day and therefore the family economy, the operating environment of the group, the community and the actual benefits of conversion are strong factors affecting conversion to Yiguandao. It is our opinion that there should be a research project that provides exclusive focus on this particular phenomenon.

The Stieng people are a minority community in the south of Vietnam with a history of co-habitance with other ethnic communities. The Stieng people have established a unique cultural identity of polytheism and basic traditional beliefs in which, "the world and everything have their own souls. All things have gods residing inside, who have the strength and power (such as God of Mountain, God of Forest, God of Sun, God of Moon, God of Wind, God of Rain) (Tran, 2011) Characteristic of the religious belief structure of the Stieng people is a communal worship of Yang Lieng (the God who opened the land for the Stieng people) and Tutba (God of Fire). The special belief in these two gods manifests very clearly in traditional festivals such as the ceremony to worship the God of Rice, the ceremony to celebrate the new offerings, the ceremony worshipping the God of Forest and the ceremony of buffalo sacrifice ${ }^{14}$ (Tran, 2011).

In recent years, a large number of Stieng people have converted to other religions such as Protestantism, Catholicism, or Buddhism. Statistics shows that the majority of Stieng people in the south of

13 Truong Van Chung (project manager), 2014. "New religions: policy and implication issues on religions in Ho Chi Minh City today", (key research project VNU -HCM 2012 - 2014). p.373

${ }^{14}$ As above, p. 27 
Vietnam have converted to Protestantism. ${ }^{15}$ Stieng people have changed the basic structure of their "religious belief" in a number of ways when becoming Protestant. The first change is the shift from a "polytheistic faith" to a "monotheistic faith". The "belief in God" has become the core belief and there is a phasing out of their traditional beliefs in multiple gods. The Stieng Protestants no longer believe in the gods of their traditional beliefs and thus no longer participate in the religious activities of the community in order to not involve themselves "in the ritual practices and superstitious activities" and or "worshipping idols" (Chung, 2014). There has been a change in theory, religious beliefs, feelings and emotions which has led them to new religious beliefs. This is also changing the worldview of the community of Stieng people. The Stieng community of Protestant denomination believes only in a single supernatural power - God. For them, God "is the highest, standing above all gods and demons" and "supreme deity to protect and help them have a better life, a peaceful and happy life and more". The notable features of the case of Stieng people converted to Protestantism are as follows.

1. The conversion of Stieng people to Protestantism is a conversion from polytheism to monotheism, in which change of belief is the factor deciding the conversion of the individuals and community.

2. Conversion to Protestantism has brought some positive changes in the community life of Stieng people and contributed towards a healthy cultural life. This includes the elimination of many backward and superstitious practices and costly ritual worship. However, from the perspective of traditions, cultural identity, family structure, ethnicity and community relationships and particularly the stability of sustainable community development there are many serious issues regarding family and community

15 According to 2011 statistics, 45\% of 60000 Stieng people in the South are Protestants (Source: Van Van Bang, The development of Protestantism in the Stieng community in Song Be Province: reality and solutions, p.56) 
conflicts, fading traditions and cultural identities and so forth that need to be considered.

3. The conversion to Protestantism of the Stieng community is an objective process that may contain contradictions, temporary collisions between members of a family and the community relations of Stieng people. However, the transition to Protestantism brings many benefits to the community such as abandoning destructive practices (alcoholism, smoking, superstition, domestic violence). We believe that the transition to the Protestant denomination is beneficial to the Stieng communities' problems and contributes toward helping them retain their national identity.

The research regarding religious conversion in the community of ethnic minorities in the southern region of Vietnam is a significant issue of high theoretical and practical value. It requires rigorous and multidimensional scientific studies. In this paper, we report the initial observations from a field survey and attempt to raise a few critical questions that arise from our observations.

This article is not an attempt to offer a complete solution to issues related to religious conversion of ethnic minority communities. The content of the article only outlines the basic contours of the transition which is very diverse and complicated. There are many academic concerns and issues that need systematic studies.

Future studies from our group will continue to review and study the various complexities involving religious conversions in southern Vietnam today. Currently, we have begun a project on the theme "The phenomenon of religious conversion and the new religion in the South, Vietnam - The problems of theory and practice". This project will be carried out by researchers at the Center for the study of Religion, University of Social Sciences and Humanities, Ho Chi Minh City. ${ }^{16}$

16 Project "The phenomenon of religious conversion and the new religion in the South, Vietnam - The problems of theory and practice", located in key research programs of VNU - HCM, is funded by National university of HCM and religious organizations in HCMC. 
Truong Phan Chau Tam Religious Conversion of the Ethnic Minorities

\section{References}

1. Southern Institute of Social Science. (2013). Workshop. Some theoretical and practical issues of religious conversion of ethnic minorities in the Southern region, Ho Chi Minh City.

2. Ngoc, P. T. B. (2013). Religious conversion of the Chinese community in Ho Chi Minh City - The case of Yiguandao. HCMC National University.

3. Chung, T. V. (2015-2017). Report on the research project on Religious conversion and new religions in the south of Vietnam, HCMC National University.

4. Government Religion Board. (2012). Conclusion of five years implementing the Instruction \# 01/2005/CT - TTg by the President dated 04/02/2005 on some policies regarding Protestantism", Report ref\# 18/BC - TGCP dated 16/03/2012.

5. Hop, T. H. (2011). Protestantism in the Mekong Delta: reality and some issues of the development process. Paper presented at Seminar, Protestantism in Vietnam during 1975 - 2011, Hanoi.

6. Lien, T. H. (2014). Religious conversion of Khmer people in Tra Vinh Province, HCMC National University.

7. Quynh, T. T., \& Lam, N. T. (2014). Religious conversion of Khmer people in the south of Vietnam. HCMC National University Publishing House.

8. Anh, T. V. (2011). Research project of Ministry of Culture, Sport and Tourism titled Cultural life of the Stieng people in Binh Phuoc Province (BV.2009 - 079 -005).

9. Le, N.V. (Ed.). (2010). State research project on "Characteristics of belief, religions and cultural activities of the Southern communities", Ho Chi Minh City.

10. Them, T. N. (Ed.). (2013). The Viet culture in the Southwest of Vietnam. Ho Chi Minh City: Culture, Literature and Art Publishing House.

11. Sangasumana, P. (2014). The impact of forced conversion on religious harmony: Lessons of Sri Lanka, Buddhism and Millennium goals of the UN. HCMC: National University Publishing House. 
12. Thinh., N. D. (Ed.). (2012). Beliefs and belief culture in Vietnam. Hanoi: Youth Publishing House.

13. Thuy, N. C. (Ed.). (2000). The Chinese settlement in the south of Vietnam (17th Century - 1945). Hanoi: Social and Science Publishing House.

14. Chung, T. V. (2012-2014). Key research project on New religions: policy and implication issues on religions in Ho Chi Minh City today", VNU -HCM.

15. Thanh, M. (n.d). Religious conversion of Buddhist Khmer followers in Tra Vinh Province. Retrieved from Website:phatgiaonguyenthuy.com.vn/

16. Vietnam Historical Science Association. (2006). Anthropological issues of Religion. Danang: Now and Then Journal Publishing House.

17. Centre of Religious Studies, HCMC National University. (2014). Post-modernism and New religious movements in Vietnam and the world. HCMC: HCMC National University Publishing House.

18. Bang, V. V. (2011).The development of Protestantism in Stieng community in Song Be: Issues and Solutions. Ministry of Internal Affairs.

19. Ly, N. V. (1995). French customs in the society of Stieng people, Associate Doctorate Thesis on Anthropology, Ho Chi Minh City Institute of Social Sciences.

20. An, P. (2007). Social and ethnic system of Stieng people in Vietnam (mid 17 Centuary-1975). HCMC: National University Publishing House.

21. An, P. (2000). "The Stieng customary laws and the issue of forest land in Binh Phuoc today", The customary laws on rural development today. Hanoi: National Politics Publishing House.

22. An, P. \& Ha, N. T. (1995). Ethnic issues in Song Be: Marriage and Family of Stieng people.

23. Van, D. N. (1984). Social and economic features of the ethnic minorities in the southern provinces of Vietnam. Hanoi: Social Sciences Publishing House.

24. Hoa, D. D. (1984). Ethnic minorities in Vietnam: the Stieng people. Hanoi: Social Sciences Publishing. 
Truong Phan Chau Tam Religious Conversion of the Ethnic Minorities

25. Duong, M. (1985). Social changes of ethnic communities in Song Be province after August 1995 Revolution until present in Ethnic issues in Song Be province. Song Be: Song Be General Publishing House.

26. Lien, T. H. (1997). Beliefs of the Stieng people in Song Be today, Ethnographic Journal, 4, 46 - 53.

27. Kinh, D. T. (2006). The separation of belief from superstition, Religious Studies Journal, 6.

28. Van, P. D. (2003). Belief and Reason, Religious Studies Journal, 5, HCMC Southern Institute of Social Sciences.

29. Government Religious Board. 2003. Overview Report: Basic survey project of the actual situation of Protestant Church of Vietnam. - Recommendations, guidelines and policies, Hanoi.

30. Cassirer, E. (1953). Antropologia filosofica. Retrieved from www. Free Ebooks. Net.

31. Jones, L. (2005). Encyclopedia of religion. New York: Thomson Gale.

32. Rambo, L. R. (2001). Theory conversion. New York: Thomas Nelson Publishers.

33. Machalek, R., \& Snow, D. (1993). Conversion to New Religious Movements in D. G. Bromley and J. K. Hadden (Ed.), Handbook of Cults and Sects in America, Vol. B. Greenwich, Conn.: JAI.

34. Malony, H. N., \& Southard, S. (Eds.).(1992). Handbook of Religious Conversion. Birmingham, Ala.: Religious Education Press.

35. Lofland, J., \& Skonovd, N. (1981). Conversion Motifs, Journal for the Scientific Study of Religion, 20, 373-385.

36. Lofland, J., \& Stark, R. 1965. Becoming a World-Saver: A Theory of Conversion to a Deviant Perspective, American Sociological Review, 30, 862-875.

37. Straus, R. (1979). Religious Conversion as a Personal and Collective Accomplishment, Sociological Analysis, 40, 158-165. 
38. Barro, R. J., Hwang, J., \& McCleary, R. M. (2001). Religious Conversion in 40 Countries. Cornerstone Research: Harvard University.

39. Rambo, L. R. (1993). Understanding Religious Conversion. New Haven, CT: Yale University Press.

40. Rambo, L. R. (1987). Conversion. In M. Eliade (Ed.), The Encyclopaedia of Religion, 4. New York: Macmillan Publishing Company.

41. Hefner, R., W. (Ed.).(1993). Conversion to Christianity: Historical and Anthropological Perspectives on a Great transformation, Berkeley: University of California Press.

42. Malik, M. A. (1989). Conversion to Islam: Untouchables' Strategy for Protest in India. Chambersburg, PA: Anima Publications.

43. Machalek, R., \& Snow, D. (1993). Conversion to New Religious Movements. In D. G. Bromley and J. K. Hadden (Ed.), Handbook of Cults and Sects in America, B, 53-74. Greenwich, Conn.: JAI.

44. Chana, U. (1989). The Transformed Self: The Psychology of Religious Conversion. New York: Plenum Press.

45. Eileen, B. (1984). The Making of Moonie: Choice or Brainwashing? Hampshire: Gregg Revivals.

46. James, B. (1978). Accounting for Conversion, British Journal of Sociology, 29 (2), 249-262.

47. Clarke, P. B. (Ed.).(1987). The New Evangelists: Recruitment Methods $\mathcal{E}$ Aims of New Religious Movements. London: Ethnographica.

48. Chung, T. V. (2013). The conversion to Protestantism: A Challenge in Ethnic and Religious Life of Brahmanism Cham People in Ninh Thuan Province, Vietnam", Tattva Journal of Philosophy, 5(2).

49. Chen, J. J. F. (2009). Understanding Yguandao. Taiwan: Publishers Center church teachings of Yguandao. 